\title{
„Idea rosyjska” w ideologii Putina
}

Wiemy, że nie odgrodzimy się już teraz od ludzkości murem chińskim. Przewidujemy, że charakter naszej przyszłej działalności powinien być w najwyższym stopniu wszechludzki, że idea rosyjska może stać się syntezą wszystkich tych idei, które z takim uporem, z takim męstwem rozwija Europa w odrębnych swoich narodowościach; iż możliwym jest, że sprzeczności tych idei znajdą swoje rozwiązanie i dalszy rozwój w narodowości rosyjskiej

- pisał Fiodor Dostojewski w 1860 roku$^{1}$.

Tym zdaniem pisarz wprowadził na stałe do rosyjskich rozważań historiozoficznych romantyczną kategorię „idei rosyjskiej”. Najczęściej była ona podstawą rosyjskiego nacjonalizmu, misjonizmu, rozważań o Moskwie - Trzecim Rzymie, utożsamiano ją z prawosławiem, ale również z komunizmem. Przez dziesięciolecia wbijano Rosjanom do głowy, że „idea rosyjska” zbawi świat, potem zamienili ją na „trzecią międzynarodówkę” i przez kolejne dziesięciolecia upierali się, że są niezwykłym „narodem sowieckim”, wyzwolicielem uciskanych mas. Upadek komunizmu wysłał „ideę rosyjską” do lamusa, ale nie na zawsze. Borys Jelcyn w lipcu 1996 roku zlecił swym politologom, by wyjaśnili, „jaka idea narodowa, jaka narodowa ideologia jest najważniejsza dla Rosji”2. Wyśmiano go wówczas. Proszę jednak otworzyć Internet i wpisać cyrylicą „русская идея” - pojawi się około pół miliona wyników, zaś ponad milion przy wpisie „национальная идея” (dla porównania: „idea narodowa”

\footnotetext{
* Profesor, Stowarzyszenie Mosty Europy, https://mostyeuropy.pl/.

1 F.M. Dostojewski, Objawlenie o podpiskie na żurnat „Wremia” na 1861 g., [w:] idem, Polnoe sobranie soczinienij, t. 18, Leningrad 1978, s. 37.

2 Elcin o „nacjonalnoj idei”, „Nezawisimaja gazeta” 1996, 13.07., s. 1.
} 
po polsku - tylko 13 500, „national idea” po angielsku - 133 000, i to z reguły odnośnie do Rosji).

Wiktor Jerofiejew w eseju Gdybym był Polakiem (1995) odnotował różnicę w polskim i rosyjskim postrzeganiu świata:

Systemy pojęciowe są zasadniczo różne. Polak prowadzi dialog według kartezjańskich zasad logicznych, odnosząc się ze zrozumieniem do kwestii sprzeczności i mając jasne wyobrażenie o swoich interesach. Rosjanin za podstawę rozważań przyjmuje ogólne pojęcie witalności, która negliżuje - w imię ludzkości - kwestię sprzeczności interesów. Polski punkt widzenia wydaje się Rosjanom wąski i nieprzyjemnie pragmatyczny. Z kolei rosyjski światopogląd jest dla polskiej świadomości niechlujnie rozmamłany i podejrzanie totalny ${ }^{3}$.

Cztery lata później, w Encyklopedii duszy rosyjskiej pisarz zakpił sobie: „Podoba mi się bycie Rosjaninem. Podoba mi się puszczanie wszystkiego mimo uszu. Idę sobie i puszczam wszystko mimo uszu. Mówią mi, że tak nie wolno. A ja mówię: nie mówcie mi nie wolno. Nie cierpię tego. Nie zasłaniajcie mi nieba"4

Gdyby Jerofiejew napisał to dzisiaj, pomyślałbym, że parodiuje Putina, ale w 1999 roku o ówczesnym szefie FSB wiedział zapewne bardzo mało lub wręcz nic. Wypunktował jedynie prześmiewczo cechy, które uznał za rosyjskie: „Rosjanie nie wiedzą, czym jest norma. Widzą, że inni żyją inaczej, ale im to nie wychodzi. Mijają lata - nie wychodzi. Niemcom wychodzi, wychodzi Japończykom. Po co tutaj? I wszyscy nie tyle się cieszą, co specjalnie nie niepokoją. Wielkie rzeczy"s.

Minęły lata i Putinowi również nie wyszło. Miała być „norma” - czyli „dyktatura prawa”. W „mentalności rosyjskiej” nigdy nie było tradycji poszanowania prawa. Rozum, Prawo - to Zachód, Rosja zaś - to Wiara i Łaska. Po stronie prawa opowiadali się liberałowie-okcydentaliści w imię praw człowieka, praw obywatelskich, myśliciele konserwatywni przeciwstawiali prawu moralność. „Prawo moralne powinno zawsze stać ponad prawem stanowionym” - powtarzali słowianofile, Dostojewski, Lew Tołstoj, a w ślad za nimi Aleksander Sołżenicyn i wielu innych głosicieli idei szczególnej drogi rozwoju Rosji. „Dyktatura prawa" (hasło wyborcze Putina przed pierwszą kadencją) wpisywała go jednoznacznie w tradycję okcydentalizmu. Dyktat moralny prowadzi do podporządkowania wszystkiego własnemu pojmowaniu świata, dyktat prawa stanowionego porządkuje sferę polityki, ekonomii i życia społecznego. Była nadzieja

3 A. de Lazari (red.), Dusza polska i rosyjska (od Adama Mickiewicza i Aleksandra Puszkina do Czesława Miłosza i Aleksandra Sołżenicyna): materiały do „katalogu” wzajemnych uprzedzeń Polaków i Rosjan, Warszawa 2003, s. 460.

4 W. Jerofiejew, Encyklopedia duszy rosyjskiej. Romans z encyklopedia, Warszawa 2001, s. 31.

5 Ibidem, s. 26. 
na zmianę mentalności rosyjskiej, gdyż Putin zwrócił się do wyborców przed pierwszą swoją kadencją takimi słowy:

Im silniejsze państwo, tym bardziej wolna jednostka. W demokracji wasze i moje prawa są ograniczone jedynie takimi samymi prawami innych ludzi. W oparciu o uznanie tej prostej zasady budowane jest prawo, którym kierować powinni się wszyscy - od przedstawiciela władzy do zwykłego obywatela. Demokracja - to dyktatura prawa, a nie ludzi na stanowiskach, którzy są zobowiązani tego prawa bronićc.

Zwyciężyła jednak tradycyjna w Rosji dyktatura „ludzi na stanowiskach”. Putin, zamiast „po europejsku” być obrońcą prawa stanowionego, zaczął „po słowianofilsku” bronić swoiście pojmowanej moralności w imię „idei rosyjskiej”.

Kategoria „idei rosyjskiej” po raz pierwszy pojawiła się w jego wypowiedzi 30 grudnia 1999, gdy szykował się do wyborów i przedstawiał swój program w referacie Rosja na przełomie wieków. W rozdziale Szanse na godna przyszłość punktem „A” jest Idea rosyjska. Składają się na nią: patriotyzm, mocarstwowość, państwowotwórczość i solidarność społeczna. „Wyobrażam sobie - mówi Putin - że nowa idea rosyjska narodzi się jako stop, jako organiczne połączenie wartości ogólnoludzkich z rdzennymi wartościami rosyjskimi, które wytrzymały próbę czasu"7. Podkreśla przy tym, że indywidualizm i wartości liberalne mają głębokie tradycje historyczne w USA i Anglii, w Rosji natomiast przewagę ma kolektywizm, zaś źródłem i gwarantem porządku społecznego oraz inicjatorem wszelkich zmian jest państwo, a nie jednostka. Trudno mu nie przyznać racji.

W lutym 2004 roku Putin wypowiada się już mniej „romantycznie”, tym razem występuje jako technokrata: „Musimy być bardziej konkurencyjni we wszystkim - i człowiek, i gałąź, i ludność, i kraj. To powinna być nasza podstawowa idea narodowa”". Rok później przekonuje, wydawałoby się sensownie, przywołując słowa filozofa-nacjonalisty Iwana Iljina, że

Władza państwowa ma swoje granice, wytyczone faktem, że występuje z zewnątrz wobec człowieka... I wszystkie twórcze stany duszy, zmierzające do miłości, wolności i dobrej woli, nie podlegają władzy państwowej i nie mogą jej podlegać... Państwo nie może żądać od obywateli wiary, modlitwy, miłości, dobroci i przekonań. Ono nie może ważyć się regulować twórczości naukowej, religijnej i artystycznej... Nie powinno ingerować

6 Zob. „Otkrytoje pismo” izbiratelam, 25 fiewrałja 2000 goda, http://kremlin.ru/events/ president/transcripts/24144 [dostęp: 15.02.2015].

7 W. Putin, Rossija na rubeże tysiaczeletij, „Nezawisimaja gazeta” 1999, 30.12., http:// www.ng.ru/politics/1999-12-30/4_millenium.html [dostęp: 15.02.2015].

8 Putin - nacjonalnoj idejej Rossii dolżna stat konkurentnosposobnost strany, http://ria.ru/ economy/20040212/526193.html [dostęp: 16.02.2015]. 
w moralne, rodzinne i codzienne życie ludzi i bez szczególnej potrzeby ograniczać ich inicjatywy gospodarcze ${ }^{9}$.

Takie wypowiedzi Putina, jego hasło wyborcze z pierwszej kadencji („dyktatura prawa”) oraz jego „niemiecka” aktywność sprawiły, że w 2004 roku swój tekst w „Przeglądzie Politycznym” zatytułowałem Pozytywista Putin ${ }^{10}$. Wiktor Jerofiejew zaś tak ocenił pierwsze dwie kadencje:

Czego dobrego dokonał Putin w ciągu ośmiu lat swych rządów? Dokąd dąży Miedwiediew? Bez zastanowienia odpowiedziałbym: za ich panowania Rosja otrzymała unikalną możliwość wolnego, prywatnego życia. Tu kryje się zagadka popularności władzy, której nie może zrozumieć Zachód. [...] I wreszcie możemy, w zależności od posiadanych pieniędzy, pojechać albo do Włoch, albo na Wyspy Wielkanocne. Zapewne właśnie to nazywa się ,autorytaryzmem z ludzką twarzą" [...]. Życie prywatne jest ratunkiem dla Rosji. Dzięki niemu, dzięki stopniowemu rozwojowi wartości rodzinnych, Rosja może wyjść na drogę oświecenia i modernizacji i znaleźć się we wspólnocie krajów demokratycznych ${ }^{11}$.

Zawiedliśmy się. W 2011 roku w wywiadzie dla „VIP Premier” na pytanie:

Czy nie wydaje się Panu, że po rozwiązaniu w ostatnim dziesięcioleciu najważniejszych palących problemów doszliśmy do konieczności urzeczywistnienia zmian jakościowych, do swego rodzaju przerwania frontu we wszystkich dziedzinach życia kraju? Czy do tego potrzebna jest nowa platforma ideologiczna - tak zwana nowa idea narodowa? Co powinno być jej podstawowym postulatem?

- Putin odpowiedział:

Bardzo często zadają mi to pytanie, pozwolę więc sobie na powtórzenie i zacytowanie słów Aleksandra Sołżenicyna, który pewnego razu określił naszą ideę narodową jako sbierieżenije naroda [zachowanie, ustrzeżenie narodu - A.L.]. W tym zwrocie zawarł się właściwie podstawowy cel współczesnej Rosji, wszystkich przemian, które zachodzą w gospodarce, sferze socjalnej, w życiu społecznym i politycznym ${ }^{12}$.

Czym jest owo sbierieżenije naroda, ze słów Putina jednoznacznie nie wynika. Gdy przywoływał tę kategorię pięć lat wcześniej w Przesłaniu do Zgromadzenia Narodowego (2006), był to dla niego problem demograficzny, jeden z kluczowych problemów do rozwiązania, a nie „idea narodowa”13.

9 W. Putin, Posłanije Federalnomu Sobraniju Rossijskoj Federacii (25 aprela 2005), http:// archive.kremlin.ru/text/appears/2005/04/87049.shtml [dostęp: 17.02.2015].

10 A. de Lazari, Pozytywista Putin, „Przegląd Polityczny” 2004, nr 66, s. 137-139.

11 W. Jerofiejew, Rosyjska apokalipsa: Próba eschatologii artystycznej, Warszawa 2008, s. 10-11.

12 W. Putin, Rossji nużna stabilnost, „VIP Premier” 2011, nr 4-5, http://www.vip-premier. $\mathrm{ru} /$ inside.php?action=statia\&id=7088\&pid=670 [dostęp: 16.02.2015].

13 Idem, Postanije Federalnomu Sobraniju Rossijskoj Federacii, http://archive.kremlin.ru/appears/ 2006/ 05/10/1357_type63372type63374type82634_105546.shtml [dostęp: 18.02.2015]. 
Wszystko staje się jasne w grudniu 2012 roku, gdy w kolejnym Przesłaniu do Zgromadzenia Narodowego Putin stwierdza: „w patriotyzmie widzę konsolidującą bazę naszej polityki”, zaś Andriej Isajew, zastępca sekretarza generalnego Jedinoj Rossii, wyciąga z tych słów wniosek, że „projektem Putina - ideą rosyjską XXI wieku” jest „idea patriotyzmu”. Wcześniej w historii Rosji - mówi Isajew - patriotyzm był podporządkowany innym ideom. W Rosji carskiej hymn zaczynał się nie od słów „Boże, chroń Rosję”, a od „Boże, chroń cara”. W słynnej „trójjedni” ministra oświaty z czasów Mikołaja I, Sergieja Uwarowa („prawosławie, samodzierżawie, narodowość”), Rosji w ogóle nie było, a „naród" był na trzecim miejscu. Bolszewicy patriotyzm zanegowali w imię idei rewolucji światowej, potem podporządkowano go komunizmowi i dopiero $\mathrm{Pu}$ tin jakoby „po raz pierwszy zaproponował patriotyzm nie jako środek wspomagający, mobilizujący naród do osiągania pewnych ważnych celów, a jako podstawę całej rosyjskiej polityki”"14.

To było w grudniu 2012 roku, natomiast w styczniu, jeszcze przed wyborami, Putin opublikował tekst programowy pt. Rosja - kwestia narodowa ${ }^{15}$, którego bohaterem jest „naród rosyjski, rosyjska kultura” jako „rdzeń spinający tkankę tej unikalnej cywilizacji”. Powołując się na Iljina i Dostojewskiego, twierdzi, że rosyjska tożsamość ma „inny kod kulturowy”, że „wielką misją Rosjan jest jednoczenie, łączenie cywilizacji”. Rosyjski język, kultura, „wszechświatowa uczynność” (sformułowanie Dostojewskiego) ma połączyć „rosyjskich Ormian, rosyjskich Azerów, rosyjskich Niemców, rosyjskich Tatarów” itd. Nie używa przy tym przymiotnika „rossijskich”, który sugerowałby ich „obywatelskość”, lecz „russkich”, który określa przynależność etniczną (россиянин - to obywatel FR, русский - to etniczny Rosjanin).

W czerwcu 2013 roku w wywiadzie dla stacji telewizyjnej Russia Today Putin po raz kolejny przeciwstawia Rosję Ameryce:

Podstawą amerykańskiej samoświadomości jest idea indywidualistyczna. Podstawą rosyjskiej - kolektywistyczna. [...] Nasza świadomość, świadomość człowieka rosyjskiego podpowiada inne zadania. Coś duchowego. Coś związanego z Bogiem. Proszę zrozumieć, mamy różne filozofie życia. I dlatego nie łatwo nam z Amerykanami zrozumieć siebie nawzajem ${ }^{16}$.

Myśl tę kontynuuje na wrześniowym spotkaniu Valdai Club: „Praktyka pokazała, że nowa idea narodowa nie narodzi i nie rozwinie się według praw rynku.

14 A. Isaew, Proekt Putina: russkaja ideja XXI wieka, „Nezawisimaja gazeta” 2012, 17.12.

15 W. Putin, Rossija: nacjonalnyj wopros, 23.01.2012, http://www.ng.ru/politics/ 2012-0123/1_national.html [dostęp: 30.03.2015].

16 Poseszczenije telekanała Russia Today, 11.06.2013, http://www.kremlin.ru/news/18319 [dostęp: 3.03.2015]. 
Ani państwo, ani społeczeństwo nie zorganizowało się samo, na nic również zdało się cudze doświadczenie". Naród nie zaakceptował obcych wpływów, ponieważ „dążenie do samostanowienia, do duchowej, ideologicznej suwerenności jest nieodłączną częścią naszego charakteru narodowego". Konieczne jest odwołanie się do historii, „połączenie doświadczenia narodowego z ideą”. Kraje euroatlantyckie odeszły od swych korzeni, „w tym od wartości chrześcijańskich, będących podstawą zachodniej cywilizacji. Negowane są zasady moralne i tradycyjna tożsamość: narodowa, kulturowa, religijna, a nawet płciowa. Prowadzi się politykę, stawiającą na jednym poziomie wielodzietną rodzinę i jednopłciowy związek partnerski, wiarę w Boga i wiarę w szatana"17.

I ostatecznie wszystko jasne staje się w grudniu 2013 roku.

Wiemy - mówi Putin do Zgromadzenia Narodowego - że w świecie jest coraz więcej ludzi, którzy wspierają nas w obronie tradycyjnych wartości, które przez tysiąclecia tworzyły duchową, moralną podstawę cywilizacji każdego narodu: wartości tradycyjnej rodziny, autentycznego ludzkiego życia, w tym religijnego, nie tylko materialnego, ale i duchowego, wartości humanizmu i różnorodności świata. To jest oczywiście postawa konserwatywna. Jednak, mówiąc słowami Nikołaja Bierdiajewa, istota konserwatyzmu polega nie na tym, że przeszkadza on w posuwaniu się do przodu i w górę, ale na tym, że przeszkadza ruchowi do tyłu i w dół, do chaotycznej ciemnoty, powrotowi do stanu pierwotnego [u Bierdiajewa: do stanu przed powstaniem państw i kultur] ${ }^{18}$.

Jeżeli zdefiniujemy „ideę rosyjską" w ślad za Iwanem Iljinem (rosyjskim Dmowskim) jako „sumę pojęć, określających historyczną oryginalność i szczególne powołanie narodu rosyjskiego" i uświadomimy sobie, że Iljin jest myślicielem najczęściej przywoływanym przez Putina, że ideologię Kremla kształtują tacy nacjonalistyczni (by nie powiedzieć faszyzujący) wyznawcy Iljina jak wicepremier Dmitrij Rogozin czy szef Ruchu Narodowo-Wyzwoleńczego, deputowany Jewgienij Fiodorow, zdaniem których wredne siły Zachodu przeprowadziły w Rosji w 1991 roku „drugą liberalno-demokratyczną rewolucję" (pierwszą w 1917) i władza w Rosji w latach 90. przeszła w obce, nierosyjskie ręce ${ }^{19}$, wówczas dzisiejsza Putinowska koncepcja "idei narodowej” i sbierieżenija naroda staje się bardziej zrozumiała. W Rosji rozpoczęła się odgórna „narodowo-wyzwoleńcza rewolucja”.

Zrozumiałe staje się również postępowanie Kremla wobec Ukrainy. Tam, zdaniem kremlowskich ideologów, Zachód przy pomocy ukraińskich nacjonalistów

17 Zasedanije meżdunarodowo diskusyonnowo kluba „Wałdaj”, 19.09.2013, http://kremlin. ru/events/president/news/19243 [dostęp: 5.03.2015].

18 W. Putin, Posłanije Federalnomu Sobraniju Rossijskoj Federacii, 12.12.2013, http://www. kremlin.ru/news/19825 [dostęp: 13.03.2015].

19 Zob. „Nacjonalno-oswoboditelnoje dwiżenije” za swobodnoje wchożdenije $w$ carstwo antichrista?, http://www.rusidea.org/?a=130133 [dostęp: 18.04.2015]. 
wywołał kolejną, obcą kulturze rosyjskiej „liberalno-demokratyczną rewolucję”. Trzeba więc ratować przed nią Rosjan. „Zachód musi uznać, że Rosja ma swoje interesy narodowe i uszanować je - mówi Putin 18 marca 2014 roku do Zgromadzenia Narodowego. [...] - Nie mogę sobie wyobrazić sytuacji, gdy będziemy jeździć do Sewastopola w gości do natowskich marynarzy" ${ }^{20}$.

Na początku pierwszej swojej prezydentury we wrześniu 2000 roku Putin zaskoczył wszystkich, udając się z "pielgrzymką" do Starca w Troice-Łykowie po nauki ${ }^{21}$. Podczas trzygodzinnej rozmowy z Aleksandrem Sołżenicynem mediów nie było i szczegółów nie znamy. Faktem natomiast jest, że Putin zyskał później na pewien czas poparcie Sołżenicyna nawet w sprawie wojny w Czeczenii. Dzisiaj literaturoznawca Benedykt Sarnow w książce pt. Fenomen Solżenicyna (Moskwa 2012) stara się przekonać czytelników, że autor Rosji w zapaści wciąż jest duchowym nauczycielem Putina i że ten, punkt po punkcie, realizuje sołżenicynowską koncepcję odbudowy Rosji. Podobne sądy znajdziemy i u politologów - Paweł Swiatienkow zatytułował swoją analizę Sołżenicyn jako zwiastun Putina ${ }^{22}$.

Czy Putin rzeczywiście jest tak ideowy jak Sołżenicyn, czy to tylko gra? Bez wątpienia w krytyce Zachodu nie ustępuje pisarzowi. Natomiast nie jestem pewien, czy Sołżenicyn poparłby hurrapatriotyzm, którego wybuch Putin sprowokował, anektując Krym. Moje wątpliwości czerpię z wystąpień żony pisarza, Natalii, która, powołując się na poglądy męża, najpierw wezwała moskiewski patriarchat, by nie plątał patriotyzmu $\mathrm{z}$ fanatyzmem i nie wspierał hurrapatriotów ${ }^{23}$, a kilka miesięcy później, uznając kulturową rosyjskość Krymu, przyznała, że „z punktu widzenia prawa międzynarodowego” do Rosji można mieć pretensje za aneksję ${ }^{24}$.

Sołżenicyn nigdy nie był militarystą, zawsze nawoływał do rozstrzygania sporów w dialogu. Dzisiaj napadają na niego i na jego żonę hurrapatrioci na

20 Obraszczenije Prezidienta Rossijskoj Federacii, 18 marta 2014 goda, http://kremlin.ru/ events/president/news/20603 [dostęp: 15.02.2015].

${ }^{21}$ Starczestwo jest jedną z rosyjskich kategorii świętości. Starcy, zwykle zakonnicy, uczyli jak żyć; po takie nauki udawali się do Pustelni Optyńskiej m.in. Dostojewski i Lew Tołstoj, a i sam Tołstoj stał się świeckim Starcem, do którego po nauki „pielgrzymowali” inteligenci nie tylko rosyjscy.

22 P. Swiatenkow, Sołżenicyn kak predtecza Putina, http://www.apn.ru/column/article 20502.htm [dostęp: 30.03.2015].

23 Natalia Solżencyna o tom, poczemu RPC nie dotżna podderżiwat ura-patrioticzeskije tendencyi, http://www.gazeta.ru/comments/2014/02/05_x_5882509.shtml [dostęp: 24.04.2015].

24 Natalia Solżencyna o Stalinie, Rosji i Ukrainie, 8.10.2014, http://rustelegraph.ru/news/201410-08/Natalya-Solzhenitcyna-o-Staline-Rossii-i-Ukraine-20078/ [dostęp: 11.03.2015]. 
czele z prawosławnymi duchownymi ${ }^{25}$ i stalinistami wszelkiej maści ${ }^{26}$. Sołżenicyn wspierał Putina, gdy ten obiecywał walkę z korupcją i reformy państwa, potem krytykował go za to, „że nic nie zrobił w polityce wewnętrznej”27. Jestem przekonany, że dzisiejszej realizacji putinowskiej „idei rosyjskiej” nie poparłby i nie przyłączyłby się do krymnaszystów.

\section{Bibliografia}

de Lazari A. (red.), Dusza polska i rosyjska (od Adama Mickiewicza i Aleksandra Puszkina do Czestawa Miłosza i Aleksandra Solżenicyna): materiały do „katalogu” wzajemnych uprzedzeń Polaków i Rosjan), Warszawa 2003.

de Lazari A., Pozytywista Putin, „Przegląd Polityczny” 2004, nr 66, s. 137-139.

Dostojewski F.M., Objawlenie o podpiskie na żurnat "Wremia” na 1861 g., [w:] F.M. Dostojewski, Polnoe sobranie soczinienij, t. 18, Leningrad 1978.

Elcin o „nacjonalnoj idei”, „Nezawisimaja gazeta” 1996, 13.07.

Isaew A., Proekt Putina: russkaja ideja XXI wieka, „Nezawisimaja gazeta” 2012, 17.12.

Jerofiejew W., Encyklopedia duszy rosyjskiej. Romans z encyklopedia, Warszawa 2001.

Jerofiejew W., Rosyjska apokalipsa: Próba eschatologii artystycznej, Warszawa 2008.

"Nacjonalno-oswoboditelnoje dwiżenije” za swobodnoje wchożdenije w carstwo antichrista?, http://www.rusidea.org/?a=130133 [dostęp: 18.04.2015].

Natalia Solżencyna o Stalinie, Rosji i Ukrainie, 08.10.2014, http://rustelegraph. ru/news/2014-10-08/Natalya-Solzhenitcyna-o-Staline-Rossii-i-Ukraine-20078/ [dostęp: 11.03.2015].

Natalia Solżencyna o tom, poczemu RPC nie dołżna podderżiwat ura-patrioticzeskije tendencyi, http://www.gazeta.ru/comments/2014/02/05_x_5882509. shtml [dostęp: 24.04.2015].

„Otkrytoje pismo” izbiratelam, 25 fewrała 2000 goda, http://kremlin.ru/events/ president/transcripts/24144 [dostęp: 15.02.2015].

Obraszczenije Prezidienta Rossyjskoj Federacji (18 marta 2014 goda), http:// kremlin.ru/events/president/news/20603 [dostęp: 15.02.2015].

25 A. Szumskij, I wnow sotżencyskoje wysokomerije!, http://ruskline.ru/news_rl/2014/ 02/05/i_vnov_solzhenicynskoe_vysokomerie/ [dostęp: 4.06.2015].

26 Zob. Ł. Saraskina, O stalinizaciji gołownogo mozga, http://www.pravmir.ru/lyudmilasaraskina-o-prityagivanii-citat-i-stalinizacii-golovnogo-mozga/ [dostęp: 8.07.2015].

27 Natalia Solżencyna o Stalinie, Rosji i Ukrainie... 
Poseszczenije telekanała Russia Today, 11.06.2013, http://www.kremlin.ru/ news/18319 [dostęp: 3.03.2015].

Putin - nacjonalnoj idejej Rossii dolżna stat konkurentnosposobnost strany, http://ria.ru/economy/20040212/526193.html [dostęp: 17.02.2015].

Putin W., Posłanije Federalnomu Sobraniju Rosijskoj Federacii, http://archive.kremlin.ru/appears/2006/05/10/1357_type63372type63374type82634_105546.shtml [dostęp: 18.02.2015].

Putin W., Posłanije Federalnomu Sobraniju Rosijskoj Federacii (12.12.2013), http://www.kremlin.ru/news/19825 [dostęp: 13.03.2015].

Putin W., Posłanije Federalnomu Sobraniju Rossijskoj Federacii (25 aprela 2005), http://archive.kremlin.ru/text/appears/2005/04/87049.shtml [dostęp: 17.02.2015].

Putin W., Rossija na rubeże tysiaczeletij, „Nezawisimaja gazeta”, 30.12.1999, http:// www.ng.ru/politics/1999-12-30/4_millenium.html [dostęp: 15.02.2015].

Putin W., Rossija: nacjonalnyj wopros, 23.01.2012, http://www.ng.ru/politics/ 2012-01-23/1_national.html [dostęp: 30.03.2015].

Putin W., Rossiji nużna stabilnost, „VIP Premier” 2011, nr 4-5, http://www.vippremier.ru/inside.php?action=statia\&id=7088\&pid=670 [dostęp: 16.02.2015].

Saraskina Ł., O stalinizaciji gołownogo mozga, http://www.pravmir.ru/ lyudmila-saraskina-o-prityagivanii-citat-i-stalinizacii-golovnogo-mozga/ [dostęp: 8.07.2015].

Swiatenkow P., Sołżenicyn kak predtecza Putina, http://www.apn.ru/column/ article20502.htm [dostęp: 30.03.2015].

Szumskij A., I wnow sołżencyskoje wysokomerije!, http://ruskline.ru/news_ rl/2014/02/05/i_vnov_solzhenicynskoe_vysokomerie/ [dostęp: 4.06.2015].

Zasedanije meżdunarodowo diskusyonnowo kluba „Wałdaj”(19.09.2013), http:// kremlin.ru/events/president/news/19243 [dostęp: 5.03.2015].

\begin{abstract}
It was Fedor Dostoevskii who introduced the category of "Russian idea" into ideological discussion. Today the category is again in its heyday in Russian nationalism and appears even in Vladimir Putin's statements. Some believe that Putin puts Aleksandr Solzhenitsyn's concept into practice. In my text I attempt to question this stance.
\end{abstract}

Keywords: Russian idea, Putin, Dostoevsky, Solzhenitsyn 